\title{
Albumin Cayemite: A Negro Plasma Albumin Variant
}

\author{
L. R. Weitkamp, A. Basu, J. C. Gall, and W. Brown \\ Department of Human Genetics, University of Michigan Medical School \\ Department of Anatomy, University of North Carolina Medical School \\ Department of Pediatries, University of Michigan Medical School
}

Received December 13, 1968

\begin{abstract}
Summary. An inherited variant of human serum albumin has been found in a Negro family from Haiti. The variant is electrophoretically distinguishable from ten different previously reported types of albumin variants.

At least ten different types of human serum albumin variants have been distinguished by starch gel electrophoresis (WEITKAMP et al., 1969a; WEITKAMP et al., 1969b). Six of these have been found in Caucasians, three in American Indians and two in New Guinea indigenes. One variant, indistinguishable from the variant found in several Caucasian families, has been found in one individual with Caucasian-Negro ancestry, but no clearly Negro variant has yet been reported (Borrs et al., 1966; WEITKAMP et al., 1969a). In conjunction with multidisciplinary projects undertaken for other purposes we have examined 483 Negro sera for albumin variants, and now report a variant distinguishable from the ten previously defined types of variants.
\end{abstract}

\section{Materials and Methods}

Blood samples were obtained from 160 Negro school children in Savannah, Georgia, and 323 individuals from two villages on Grande Cayemite Island $\left(18^{\circ} 40^{\prime} \mathrm{N}\right.$ and $\left.78^{\circ} 40^{\prime} \mathrm{W}\right)$, Haiti. For the Haiti samples, for each village, a $50 \%$ random sample of households was drawn from a list of all households in the village, using a table of random numbers. Blood samples were collected from almost all the adults (20 years or over) in the sample of households, from 186 persons out of a total population of 853 in Anse a Maçon and from 137 persons out of a total population of 475 in Pointe Sable. The specimens from Georgia were drawn from children in school, with no systematic effort to make the sample random.

Electrophoresis was performed using the two vertical starch gel systems detailed in Weitkamp et al. (1969a) (Lot 350, Electro Starch Co., Madison, Wisconsin): the samples from Georgia were examined in the tris-EDTA-borate, $\mathrm{pH} 6.9$ system; those from Haiti in the acetate-EDTA, pH 5.0 system. In addition the new albumin variant was compared with other slowly migrating variants in the tris-lithium-succinate-citrate, $\mathrm{pH} 6.0$ system of ARENDS et al. (1969). (Electrophoresis was continued for 19 hours at 10 volts $/ \mathrm{cm}$.)

\section{Results and Diseussion}

Of the 483 Negroes examined, two individuals from the village of Anse a Maçon, Grande Cayemite Island, Haiti were found to have a variant plasma albumin phenotype. The variant migrates more slowly than normal albumin and 
is different from five previously reported slowly migrating types of albumin variant (Fig. 1). It was found in a mother and son, a pattern consistent with the autosomal inheritance which has been found for other albumin variants. The mother, son and also two sons with the normal albumin phenotype were all

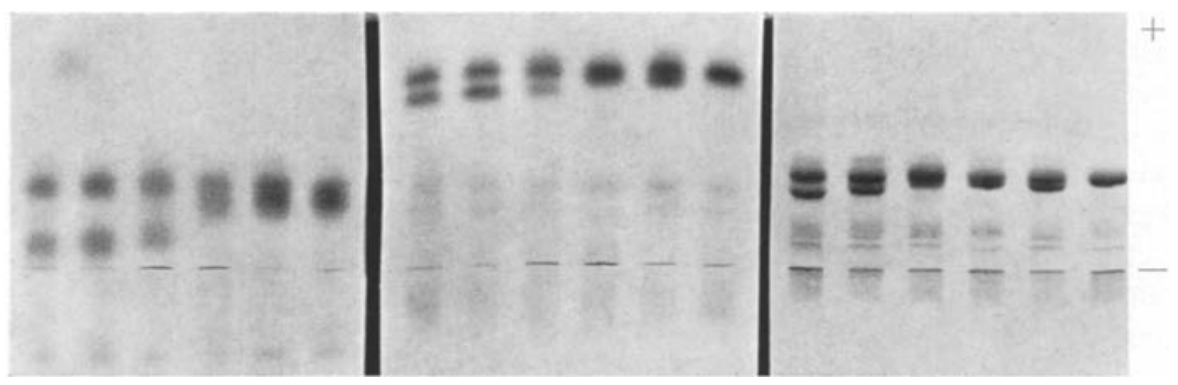

Fig. 1. Comparative vertical starch gel electrophoresis of albumin Cayemite with five previously described slowly migrating albumin variants. Gels: A: acetate-EDTA, pH 5.0. B: tris-lithiumsuccinate-citrate, pH 6.0, C: tris-EDTA-borate, pH 6.9. Position 1, Family 10; 2, Family 24; 3, Family 11; 4, Albumin Cayemite; 5, Albumin Mexico; 6, Albumin Uinba. (Reference to previous descriptions of these variants is given in the Table.) All samples contain both a variant and the common type of albumin.

homozygous for the $\mathrm{Gc}^{1}$ allele; hence the family does not contribute evidence concerning the genetic linkage between loci for albumin and Ge which has been previously reported for other albumin variants (WEITKAMP et al., 1966; KaARSALO et al., 1967; WEITKAMP et al., 1968). We suggest the new variant may be identified as albumin Cayemite until the structural basis for its difference from normal is determined.

The six slowly migrating variants shown in Fig. 1 were distinguished using three different starch gel electrophoretic systems. No one system was capable of distinguishing all the variants (and normal albumin) from each other. In addition, since the differences in mobility within a system are in some instances quite

Table. Relative electrophoretic mobility of six slowly migrating serum albumin variants in three starch gel systems ${ }^{a}$

\begin{tabular}{llll}
\hline Identification $^{\mathrm{b}}$ & $\mathrm{pH}$ 5.0 & $\mathrm{pH}$ 6.0 & $\mathrm{pH} \mathrm{6.9}$ \\
\hline Family 10 & 1 & 1 & 1 \\
Family 24 & 1 & 1 & 2 \\
Family 11 & 2 & 2 & 5 \\
Albumin Cayemite & 3 & 4 & 4 \\
Albumin Mexico (Family 30) & 4 & 3 & 3 \\
Albumin Uinbac & 4 & 5 & 6 \\
\hline Normal Albumin & 5 & 5 & 6 \\
\hline
\end{tabular}

a See text for description of electrophoretic conditions; mobility: $1<2<3<4<5<6$.

b Family numbers were previously listed in WEITKAMP et al. (1969a).

c Described in WEITKaMP et al. (1969 b). 
small, the differences in relative mobilities among the systems serves to more clearly distinguish each type of variant. The relative mobilities in each system are summarized in the Table.

It is of particular interest that the variant found in Family 11 migrates more slowly than albumin Cayemite and albumin Mexico in the $\mathrm{pH} 5.0$ and 6.0 systems and more rapidly than the latter in the pH 6.9 system. Albumin Cayemite, on the other hand, migrates relative to albumin Mexico more slowly in the pH 5.0 system and more rapidly in the $\mathrm{pH} 6.0$ and 6.9 systems. A similar reversal in mobility in different buffer systems has also been noted among the rapidly migrating albumin variants (WEITKamp and Chagnon, 1968). Harris et al. (1968) have demonstrated that a change in the mobility of acid phosphatase A relative to acid phosphatase $B$ and $C$ was due simply to the presence of citrate in one buffer system. Thus, in addition to differences in $\mathrm{pH}$ among the albumin buffer systems, another possible explanation for these instances of reversed electrophoretic mobility of the variants is differential binding of buffer ions. The hypothesis is certainly consistent with the ability of albumins to bind small ions; it also suggests the possibility of differential functional capacities of the variants.

Acknowledgements. We kindly thank Dr. H. M. VANDIVItere, Director, Haitian-American Tuberculosis Institute, and Dr. F. Audous, Minister of Public Health, Haiti, for help in obtaining the specimens from Haiti, Dr. W. W. Oтто, Assistant Superintendent, Chatham County Health Department, for help in obtaining the specimens from Georgia, and Mrs. K. RYAN for technical assistance. This investigation was supported in part by U.S. Atomic Energy Commission Contract $\mathrm{AZ}(\mathbf{1 1}-\mathbf{1})-1552$, the Carolina Population Center, and National Institutes of Health Grant HD-02083.

\section{References}

Arends, T., M. L. Galtango, M. Layrisse, J. Wilbert, and H. D. Heinei: Albumin Warao: New Type of Human Alloalbuminemia. Blood (in press) (1969).

Bohls, S. W., F. Y. Lara, N. Thruman, and J. Keyes: Manifestation of bisalbuminemia in serum and cerebrospinal fluid. Dis. nerv. Syst. 27, 727-728 (1966).

Harris, H., D. A. Hopkinson, J. E. LufFMan, and S. Rapley : Electrophoretic variation in erythrocyte enzymes. In: Hereditary Disorders of Erythrocyte Metabolism, ed. E. Bevtler. City of Hope Symposium Series, Vol. I, pp. 1-20. New York: Grune and Stratton 1968.

KaARsalo, E., L. Metartin, and B. S. Bucmiberg: Autosomal linkage between the albumin and Go loci in humans. Science 158, 123-125 (1967).

Weitkamp, L. R., G. Franglen, D. A. Rokala, H. F. Polesky, N. E. Simpson, F. W. Sunderman, JR., H. E. BhLl, J. SAAve, R. Lisker, and S. W. Bohls: An electrophoretic comparison of human serum albumin variants: eight distinguishable types. Human Heredity 19, 159-169 (1969a).

-, E. B. Robson, D. C. Shrefrler, and G. Corney : An unusual serum albumin variant: Further data on genetic linkage between loci for human serum albumin and Group Specific Component (Gc). Amer. J. hum. Genet. 20, 392-397 (1968).

-, D. L. RuckNaGer, and H. Gershowitz: Genetic linkage between loci for human serum albumin and Group Specific Component (Gc). Amer. J. hum. Genet. 18, 559-571 (1966).

-, D. C. Shreffletr, and J. J. SAAVE: Serum albumin variants in New Guinea indigenes. Vox Sang. (Basel) (in press) (1969 b).

Dr. LOWELL WeitKamp

Department of Human Genetics

University of Michigan Medical School

Ann Arbor, Michigan 48104 (U.S.A.) 